\title{
NIGERIA 2015 PRESIDENTIAL ELECTION: THE VOTES, THE FEARS AND THE REGIME CHANGE
}

\author{
Mojeed Adekunle Animashaun \\ Mojeed Adekunle Animashaun is a lecturer and Head of Department \\ in the Department of Political Science and Public Administration at \\ Fountain University, Osogbo, Nigeria \\ email: kunlemashaun@yahoo.com
}

\begin{abstract}
Nigeria's 2015 presidential election has been a landmark in the country's political history. As the fifth round of elections since the restoration of constitutional rule in 1999, it not only resulted in an alternation of power for the first time in the democratic history of Africa's largest democracy, but its outcome is widely acknowledged as substantially reflecting the wishes of the electorate. This paper reviews the 2015 presidential contest in Nigeria. It observes that, while the election conferred broad legitimacy on the postelection regime, the expectations that accompany the electoral outcome are a huge challenge for the Buhari administration. The paper identifies some factors that may challenge the aspirations of the new government. It also identifies useful lessons that can be drawn from the outcome of the election. These lessons have implications not only for the management of future elections but, more importantly, for efforts at deepening democratic rule in Nigeria.
\end{abstract}

Keywords: election, presidential election, Nigeria, political parties, electoral violence, alternation of power.

\section{INTRODUCTION}

Between March and April 2015, Nigerians went to the polls to cast their ballot in national and state elections. These elections were the fifth round of general elections since the country's democratic rebirth in 1999, in which constitutional 
rule was restored after a military dictatorship that lasted 15 consecutive years. The intense anxiety that preceded the 2015 elections, the global interest they generated, and the alternation of power which the presidential vote engendered, all combined to make the election a landmark in the chequered political history of Nigeria.

Through the elections, Nigerians had the opportunity either to choose 'continuity', as represented by the incumbent President Dr Goodluck Jonathan and his ruling People's Democratic Party (PDP), or to embrace 'change', as symbolised by the opposition candidate, General Muhammadu Buhari of the All Progressives Congress (APC). These two leading candidates in the 2015 challenge had also encountered each other at the ballot in the 2011 presidential contest, although at that time General Buhari was running on the ticket of the defunct Congress for Progressive Change (CPC).

Analysts believe that the peaceful, transparent and credible manner in which the elections were organised, and the regime change which the presidential election produced, have launched Nigeria onto the path of democratic sustenance. The winner of the presidential election, General Buhari, has taken up the presidency with discipline, honesty, reliability and doggedness - rare attributes among the current crop of Nigerian leaders. Such qualities are urgently needed to confront the daunting challenges facing the oil-rich nation.

These rare personal attributes of the General may be put to the test as he faces the task of national rebuilding, a task thrust on him by the historic mandate he secured at the historic election. Nigerians expect him to chart an entirely new course for the country that will usher in a new beginning in the nation's troubled 55 years of formal independence.

This paper reviews the 2015 presidential election in Nigeria. It examines the fluid and volatile environment in which the election was conducted, the electoral strength of competing parties, and the character of the election campaigns. The paper discusses the regime change that accompanied the presidential vote, the historical significance of the governmental turnover, and the inherent rising expectations within the polity. Lessons drawn from the election and their implications for democratic sustenance in Nigeria are also discussed.

\section{THEORETICAL FOUNDATION}

Scholars have employed diverse theoretical models to study or explain the determinants of voting behaviour and electoral outcomes. Each of these approaches seeks to identify factors that shape the attribute of 'indeterminacy' associated with elections as a mechanism for recruiting leaders within democratic contexts. 
Three main theoretical perspectives on voting decision have been identified in the literature on voting behaviour. These are the sociological theory or the Columbia school, the psychosocial theory or the Michigan school, and the rational choice theory. The framework for this study is the psychosocial approach, but all three approaches are briefly outlined here.

At the heart of the argument of each approach is the attempt to establish the main driver of voters' choices. What influences voting decisions of the electorate? Are such decisions based on a rational evaluation of the accomplishments of the candidates on offer, the record and performance of a regime, and the issue positions of competing political parties? Or are voters' choices influenced more by non-evaluative sentiments, such as ethnic, family or clientelistic ties?

The sociological theory suggests that social factors, such as socio-economic variables, religion and location, are key factors in determining voting decisions (Lazarfeld et al. 1948, p. 27). The rational choice model has two main perspectives, namely evaluation and non-evaluation. Evaluative voting rationale is premised on voters' evaluation of regime performance. By contrast, the non-evaluative perspective is based on clientelistic considerations such as patronage, ethnic and family ties (Lindberg \& Morrison 2008, p. 95).

The psychosocial perspective seeks to account for why and how electoral change occurs. This model provides a framework that combines sociological and psychological approaches to study voting decisions (Agomor \& Adams 2014, p. 3). The central argument of the psychosocial theory is that voters' political affiliation or party identification - which is understood as being a socio-psychological product - shapes those voters' evaluations of relevant matters. Thus, according to Erdman (2007, p. 63), voters evaluate the electoral candidates, campaign issues, and the expected capacity of political parties to solve governance problems.

According to this perspective, party identification is assumed to influence both the attitudes of the voters and their actual vote (Eulau 1960, p. 993). Party identification in this context refers to 'the sense of personal attachment which the individual feels toward the party of his choice' (Campbell et al. 1954, p. 88).

The theoretical argument of this paper is anchored on the assumptions of the psychosocial approach to voting behaviour. I argue that the increasing affiliation of Nigerian voters with the APC as an electoral platform, particularly as the elections approached, ensured victory for that party at the polls. The party was perceived as being a credible alternative to the incumbent party, and was credited with the capacity to midwife the much-needed national rebirth.

The growing popularity of the party was facilitated by two main factors. The first was the declining legitimacy of the PDP-led national government. The second was the general perception that the APC candidate was a man of integrity 
and discipline, who was capable of initiating the process of national rebirth and an agenda for governance renewal.

\section{PRE-ELECTION ANXIETY AND SPECTRE OF VIOLENCE: BASIS AND IMPACT ON POLLING}

The 2015 general elections in Nigeria took place within the local context of insurgency arising from the brutal activities of the extremist Islamist group, Boko Haram, in the north-eastern part of the country, and the global context marked by declining global peace. In its 2014 Global Peace Index (GPI) report, the Institute for Economics and Peace (IEP) stated that since 2008, among the countries which it ranked worldwide, 111 countries had deteriorated in their levels of peace, while only 51 countries had increased in peace during the same period (IEP 2014, p. 41).

The Boko Haram menace has resulted in the death of thousands of innocent Nigerians, massive destruction of property, and the displacement of thousands of people. This challenge conspired with the global context of declining peace to render the environment in which the Nigerian elections were conducted highly volatile. Indeed, in its special report on the Nigeria 2015 polls, the International Crisis Group (ICG), an international conflict research organisation, noted the volatile environment in which the preparations for the elections took place. This environment was marked, on the one hand, by acrimony between the two leading parties, and on the other hand by deep ethnic and religious polarisation. In its report, the ICG cautioned that if the hardening of positions among the key actors in the elections intensified, the tensions could degenerate into violence (ICG 2014, p. 3).

As Nigerians approached the polls, they were troubled by two things. First, many Nigerians were apprehensive about the much-publicised prediction that the 2015 election, and its outcome, would lead to the disintegration of Nigeria as a united territory. Second, sad memories of the 2011 post-election violence and its accompanying heavy casualties created fear among many Nigerians. The 2011 post-election violence, acknowledged as the bloodiest election-induced violence in the political history of Nigeria (Bekoe 2011; NAPEN 2011, p. 26), had resulted in the death of more than 800 people (HRW 2011).

If the prediction that Nigeria would cease to be a unified territory did not provoke national anxiety, the same cannot be said about electoral violence. Kurfi (2003, p. 8) describes such violence in Nigeria as a 'war of succession'. In a national survey conducted by Afrobarometer in December 2014, the research organisation reports that $50 \%$ of the 2400 respondents surveyed expressed fear of the likelihood of violence during the elections.

Indeed, in the period before the 2015 polls, the spectre of violence was so overwhelming that people feared that the much-celebrated 2014 Centenary might 
be the last to be organised by Nigeria as a corporate entity (Bakare 2014, p. 302). Thus, beyond the question of who would win the election, the fear of violence and the precarious status of the country as a united entity remained major concerns.

The bitter experience of Nigerians who have witnessed electoral violence has caused them to approach elections with trepidation (Yaqub 2003, p. 23). This situation apparently informed Adekanye's $(1989$, p. 11) counsel that a state of emergency be declared during periods of election, with the military taking charge at such times. Omitola (2011, p. 232) states that having risen to the point of becoming the 'de facto language of communication among political gladiators', the democratic system risked coming to grief under the weight of electoral violence.

However, the vulnerability of Nigeria to implode from within, and the entrenchment of violence in its politics, do not in any way diminish the transformational possibility and human potential that abound in Africa's largest democracy. Joseph (1991, p. 43) calls this contradiction 'the Nigerian paradox'.

The above discussion has shown that the primary basis of the pervasive fear and anxiety that preceded the elections derived from the fact that elections in Nigeria have often been violent and turbulent (Albert 2007, p. 38; Anifowose 1982; Elaigwu 2003; ICG 2014, p. 2; Nwolise 2007; Ochoche 1997, p. 16). In the case of the 2015 polls, the fear of violence was largely driven by the irresponsible conduct of politicians in the way they sought votes. Inflammatory comments and hate-laden speeches by political gladiators created tension across the polity. This was aggravated by the activities of some former militants from the Niger Delta region of the country, who not only framed the presidential election in terms of North/South or majority / minority, but also threatened to go back to the creeks and resume militancy against the democratic state if President Jonathan lost the election.

Also, as the elections approached, growing animosities and hostilities between the ruling PDP and opposition APC heightened countrywide apprehension about the elections. For instance, the PDP criticised the APC for promoting religious favouritism as a result of Muslim domination of the leadership structure of the party, labelling the party 'Nigeria's Muslim Brotherhood'.

The APC, on the other hand, described the PDP-led federal government as a huge failure particularly on account of its poor handling of the national economy and security. It also accused the PDP and its leaders of playing divisive politics that, according to the party, further deepened ethnic, regional and religious mistrust within the national society.

While ethno-linguistic and religious diversities may not drive political conflicts in other ethnically segmented contexts, in Nigeria they have become important factors in explaining political conflicts (Azeez 2004, p. 160; 
Ibeanu 2012, p. 7). Because the Nigerian state lacks autonomy from the ruling faction of the governing elite, the state is perceived as an institutional expression of private and sectional interests, leaving many groups politically and economically excluded. This exclusion tends to generate tension that often translates into politically pertinent conflicts.

The impact of this trenchantly-charged environment on the 2015 elections manifested in the generally poor voter turnout that marked both rounds of the elections. We shall return to the issue of voter apathy later in the paper.

\section{POLITICO-ECONOMIC CONTEXT OF THE POLLS}

It is imperative to understand the politico-economic context in which the 2015 elections were organised. The ecology of the polls not only shaped the character and intensity of election campaigns, but also influenced the outcome of the election.

The election took place at a time of worsening material conditions for the Nigerian citizenry. According to official records from the National Bureau of Statistics, poverty incidence grew to $69 \%$ in 2010 and was projected to rise to $71 \%$ in 2011, while the rate of unemployment in the country was estimated at $24 \%$. Add to this the effects of decaying public infrastructure and 'punitive' tax regimes introduced by government at all levels, and one can better appreciate that the elections were conducted at a most difficult juncture in the material circumstances of the Nigerian masses.

Falling oil prices on the international market and the attendant declining national revenue have thrown the oil-dependent economy into a serious crisis. One of the major consequences of the declining revenue accruing to the state as a result of oil crashes, and the attendant negative impact on state capacity for social provisioning, was the inability of government to pay emoluments of public sector workers at all levels. This included retired public servants timeously receiving their pensions from the government.

While unpaid or delayed salary payments did not constitute a serious threat to the electoral fortunes of the presidential contestants, partly because federal government is remote from citizens, the salary deficit was a strong electoral and campaign issue at state level. Many state executives, particularly those seeking mandate renewal, were pitched against public workers. Indeed, there were fears that if oil prices continued their downward spiral, elected executives might not be able to redeem their campaign promises, which would negatively affect relations between the state and civil society.

It was the former Central Bank of Nigeria (CBN) governor, Professor Chukwuma Soludo, who raised a deafening alarm about the state of health of the 
national economy. In an insightful and incisive article that provoked national debate, the former university teacher drew attention to the parlous state of the economy, with its inherent uncertainties and hard times. While lamenting that management of the troubled economy did not form a prominent issue in the election campaigns of the two leading presidential gladiators, he described the economic management approach of the Jonathan presidency as 'an empty slogan without content or direction' (Soludo 2015).

In its response to the Soludo challenge, the APC, through a rejoinder by Dr Kayode Fayemi - the Head of Policy, Research and Strategy Directorate of the party - acknowledged the concerns of the former CBN governor, outlining measures that have been designed by the party for enhancing economic growth and generating employment. Among other strategies, these included weaning Nigeria off its 'dangerous addiction to oil which currently provides $80 \%$ of our spending leaving us at the mercy of volatile international oil prices' (Fayemi 2015).

Punch reported that in the response of the federal government to the article, a senior administration official, Dr Ngozi Okonjo-Iweala - the country's Minister of Finance and Co-ordinating Minister of the Economy - described Soludo's piece as 'intellectual hara-kiri' coming from an 'embittered loser in the Nigerian political space' (Punch, 29 January 2015).

Security, with its two distinct dimensions, was another defining element in the ecology of the 2015 elections. The first dimension was the challenge posed by the murderous activities of the Boko Haram insurgents in the north-east of the country, and the implications of insurgency for the successful conduct of the elections in the affected states of Adamawa, Borno and Yobe. The second and more controversial dimension was the deployment of soldiers to police the elections. The ugly experience with the use of military personnel for the 2014 governorship election in Ekiti and Osun states in the south-west geopolitical zone of the country had raised huge doubts within the polity about the neutrality and professional conduct of state security workers.

Ruling on a litigation matter inspired by the controversy, the Sokoto High Court, presided over by Justice RM Aikawa, overruled the deployment of soldiers for election duty. Aikawa's judgment was upheld by the verdict of the Court of Appeal, Abuja Division, on 16 February 2015. The two courts held that the use of the military for election purposes constituted a gross violation of both the 1999 Constitution of the Federal Republic of Nigeria, as amended, and the Electoral Act 2010, as amended.

The rating of the two main contestants in the presidential election by foreign media was another important issue that preceded the elections. The analysis of the foreign press on the chances of the two frontline candidates expectedly spawned wide reactions across the polity. 
In its editorial column on 18 January 2015, the popular British newspaper The Observer strongly criticised the incumbent Jonathan administration for lacking the right strategies to contain the challenge of insurgency in the north-eastern part of the country. The paper further accused the administration of not telling the nation, in concrete terms, how it planned to end suicide bombings, kidnappings and other nihilistic atrocities going on in the three north-eastern states. By contrast, the newspaper wrote positive comments about General Buhari, such as 'Buhari earned a reputation for strong leadership and intolerance of corruption during his brief period in power in 1983-1985' (The Observer, 18 January 2015).

Another United Kingdom newspaper, The Guardian of London, described the two leading contestants for the presidency as 'flawed leaders'. According to this newspaper's editorial,

President Jonathan stands accused of inertness and procrastination in dealing with Boko Haram, and of ineffective performance in office generally. General Muhammadu Buhari, his rival, has a reputation as one of the more honest and well-intentioned of the country's military rulers, but not one of the most astute.

(The Guardian of London, 16 January 2015)

The influential United Kingdom magazine The Economist went a step further in its analysis, by endorsing one of the candidates. In an editorial titled 'Former Dictator is a Better Choice than a Failed President', the magazine noted that while it was unfortunate to have these two candidates running for presidency, General Buhari was the better candidate. The magazine wrote:

Start with Mr Jonathan, whose party has run the country since 1999 and who stumbled in to the presidency on the death of his predecessor in 2010, the PDP's reign has been a sorry one. Mr Jonathan has shown little willingness to tackle endemic corruption. When the governor of the central bank reported that $\$ 20 \mathrm{bn}$ had been stolen, his reward was to be sacked. He has shown little enthusiasm for tackling insecurity and even less competence.

(The Economist, 6 February 2015)

On the other hand, the magazine opined that

Buhari is a sandal-wearing ascetic with a record of fighting corruption. Few nowadays question his commitment to democracy or expect him to turn autocratic: he has repeatedly stood for election 
and accepted the outcome when he lost. He would probably do a better job of running the country, and in particular of tackling Boko Haram. As a northerner and Muslim, he will have greater legitimacy among villagers whose help he will need to isolate the insurgents. As a military man, he is more likely to win the respect of a demoralised army.

(The Economist, 6 February 2015)

There were other less prominent issues of context that received attention in the build-up to the election. These included the threat by the former Niger Delta militants to unleash violence in the country if President Jonathan lost at the polls. Members of the outlawed Oodua People's Congress (OPC) staged a progovernment rally in Lagos, Nigeria's commercial capital, on 16 March 2015. The violent protesters, who were under security cover provided by state agencies, demanded the non-use of Permanent Voter Cards (PVCs) and Smart Card Readers (SCRs) for the 2015 elections. They demanded the removal of the Chairman of the Independent National Electoral Commission, Professor Attahiru Jega, even as they endorsed the candidacy of President Jonathan.

There was also the allegation by the governor of Rivers State, Mr Rotimi Amaechi, who headed the presidential campaign committee of the APC, that the Jonathan presidency had bribed the leadership of the Christian Association of Nigeria (CAN) with a whopping sum of N7-billion to campaign against General Buhari. Although the national leadership of CAN rejected the allegation, the Executive Director of the Voice of Northern Christian Movement, Pastor Kallamu Musa-Dikwa, insisted that the national office of CAN had received the money and disbursed it to state chapters of the religious body.

This volatile context in which the elections were organised deepened local and external interest in the elections, and heightened the electoral uncertainties that confronted the two leading parties as they marched towards the historic elections.

\section{COMPETING PARTIES AND PROSPECTS OF ACCESSING POWER}

According to an official release by the Independent National Electoral Commission (INEC) on 29 December 2014, fourteen political parties fielded candidates for the 2015 presidential election. The parties were: Action Alliance (AA), African Democratic Congress (ADC), All Progressives Congress (APC), African People's Alliance (APA), Allied Congress Party of Nigeria (ACPN), Alliance for Democracy (AD), Citizens Popular Party (CPP), Hope Democratic Party (HDP), Kowa Party (KP), National Conscience Party (NCP), People's Democratic Party (PDP), People's 
Party of Nigeria (PPN), United Democratic Party (UDP), and United Progressives Party (UPP).

The names of the political parties and those of their presidential and vicepresidential candidates were published on the INEC website on 13 January 2015. Of the 26 registered parties in Nigeria before the elections, twelve did not compete for the highest elective office in the country. However, two of those parties, the All Progressives Grand Alliance (APGA) and the Labour Party (LP), adopted Dr Goodluck Jonathan of the PDP as their presidential candidate. The names of the parties and their candidates are shown in Table 1 below.

Table 1

Names of parties and candidates that contested 2015 presidential election

\begin{tabular}{|r|l|l|c|}
\hline & Party & Candidate & Gender \\
\hline 1. & Action Alliance (AA) & $\begin{array}{l}\text { ANIFOWOSHE- } \\
\text { KELANI, Tunde }\end{array}$ & $\mathrm{M}$ \\
\hline 2. & African Democratic Congress (ADC) & AHMAD, Mani Ibrahim & $\mathrm{M}$ \\
\hline 3. & All Progressives Congress (APC) & BUHARI, Muhammadu & $\mathrm{M}$ \\
\hline 4. & African People's Alliance (APA) & ADEBAYO, Ayeni Musa & $\mathrm{M}$ \\
\hline 5. & Allied Congress Party of Nigeria (ACPN) & GALADIMA, Ganiyu & $\mathrm{M}$ \\
\hline 6. & Alliance for Democracy (AD) & SALAU, Rafiu & $\mathrm{M}$ \\
\hline 7. & Citizens Popular Party (CPP) & EKE, Sam & $\mathrm{M}$ \\
\hline 8. & Hope Democratic Party (HDP) & OWURU, Ambrose & $\mathrm{M}$ \\
\hline 9. & Kowa Party (KP) & SONAIYA, Oluremi & $\mathrm{F}$ \\
\hline 10. & National Conscience Party (NCP) & ONOVO, Martin & $\mathrm{M}$ \\
\hline 11. & People's Democratic Party (PDP) & JONATHAN, Goodluck & $\mathrm{M}$ \\
\hline 12. & People's Party of Nigeria (PPN) & ALLAGOA, Kelvin & $\mathrm{M}$ \\
\hline 13. & United Democratic Party (UDP) & OKOYE, Godson & $\mathrm{M}$ \\
\hline 14. & United Progressives Party (UPP) & OKORIE, Chekwas & $\mathrm{M}$ \\
\hline
\end{tabular}

Source: Independent National Electoral Commission, 2015

In terms of electoral prospects, of the fourteen political parties that competed in the presidential election, only two - the PDP and APC - had a real chance of winning the election. The PDP was one of the three parties that had registered to contest the 1998/ 99 transition elections which had preceded the inauguration of Nigeria's Fourth Republic. In the national elections of 1999, the candidate of 
the party, Olusegun Obasanjo, won the presidential election, and the party won governorship election in 21 out of the 36 states.

The All People's Party (later renamed All Nigerian People's Party, ANPP), which was the second largest of the trio, won governorship election in nine states. The AD won in six (Aina 2004, p. 91). Since 1999, PDP has remained the ruling party in the country, having consecutively won the 2003, 2007 and 2011 presidential elections, and controlling the majority in the national legislature.

The APC was the product of a merger by four political parties. In February 2013, the Action Congress of Nigeria (ACN), the Congress for Progressive Change (CPC), the ANPP, and a faction of the All Progressives Grand Alliance (APGA) fused to form the APC. The formation of this party through a merger of leading opposition parties raised the hope that Nigeria would not descend into a oneparty democracy.

In November 2013, five sitting governors elected on the platform of the ruling PDP defected to the mega opposition party. They were Muritala Nyako (Adamawa), Rabiu Kwankwanso (Kano), Abdulfatah Ahmed (Kwara), Rotimi Amaechi (Rivers), and Aliyu Wamako (Sokoto). The party drew further public attention when 37 members of the lower chamber of the federal legislature, the House of Representatives, joined the party. Some serving members of the upper legislative chamber - the Senate - also later pitched tent with the nascent party.

Perhaps the most celebrated of the series of defections to the APC was that of the Speaker of the House of Representatives, Hon Aminu Tambuwal, in the last quarter of 2014. The APC thus went to the 2015 presidential elections not only as the most formidable challenger to the PDP, but also as the likely winner of the contest.

The low electoral appeal and followership of the other twelve political parties was reflected in the poor electoral performance posted by the parties. As the final result of the election shows, the twelve parties together recorded less than $5 \%$ of all votes cast. The low level of affection for these parties can be ascribed to the fact that many of them are not well established within the polity, and lack the resources to take their message to the voters or establish a national presence.

Indeed, most of these parties could be regarded as 'electoral machines' created for the purpose of contesting elections rather than to register a significant presence in the electoral space. For example, the AA, ACPN, ADC, and APA had been formed just before the 2011 general elections, largely as a result of crises that engulfed state chapters of the PDP. It should, however, be pointed out that some of the founders of these fledgling parties have since negotiated themselves back to the PDP, leaving the parties organisationally and materially weak.

While the $\mathrm{AD}$ is one of the oldest parties in the current republic, the crisis that hit the party in the build-up to the 2007 elections led to the fragmentation of 
the party, with a faction forming the Action Congress (later the Action Congress of Nigeria). Today, the AD, which produced six state governors in the 1999 elections, has no state under its control.

The NCP, formed by the late human rights lawyer, Gani Fawehinmi, is another relatively old party in the current democratic dispensation, which first contested elective office during the 2003 general elections. Though a modest party at its formation, drawing the bulk of its membership from the human rights community, the small electoral value attributed to the party further diminished with the death of its founder.

The UDP, UPP, PPN, HDP and KP were late entrants into the politics of Nigeria's Fourth Republic, having been formed barely two years before the 2015 polls.

\section{NATURE OF CAMPAIGNS AS A WARNING SIGNAL OF VIOLENCE}

Three major issues dominated the campaigns for the 2015 presidential election: violence, hate campaigns, and low emphasis on issue-based and developmental politics.

Hate campaigns, which manifested through hateful and abusive speeches during campaign rallies and in media advertisements, became so absurd that some eminent Nigerians - including John Cardinal Onayeikan, Catholic Bishop of Abuja; and the Nobel Laureate, Professor Wole Soyinka - counselled politicians to tread the path of honour in their electioneering activities. It was not too surprising that the campaigns were bereft of issue positions and developmental politics.

While Nigerian politics have historically been issue-free (Animashaun 2014, p. 17; Fayemi 2003, p. 130), the crash in oil prices and its implications for the national economy apparently cautioned the presidential contestants against unrealistic promises. To the extent that violence remains a salient characteristic of electoral politics in Nigeria (Omitola 2011, p. 233), it is not surprising that the 2015 elections were marked by a fear of violence and the actual outbreak of violence.

Theoretically, democracy and violence should not have any relationship, because democratic rule is associated with institutionalised mechanisms for conflict resolution. Whereas Reychler (1999, p. 59) has shown that the democratisation process is risk-laden, Eckstein \& Gurr (1975) suggest that democracy delegitimises violent acts that threaten the entire political/ democratic system.

The political elite in Nigeria and other newly-democratising countries competes for state power within the context of what Quantin (1998, p. 13) calls a normative vacuum of a 'market place where all participants try to maximise their profits'. Such context engenders violence that can only be checked by linking electoral competition to non-market values (Quantin 1998, p. 15). Seized 
by the obsessive urge to acquire returns from politics guaranteed by a primitive accumulation and patronage system, politicians regard electoral competition as warfare that they must win at all costs. This urge manifests in the desperation to access state power, retain power, and the tendency to reject election results that do not favour them.

Electoral violence involves riots, thuggery, kidnapping, arson and politicallymotivated assassination, consciously organised and targeted at influencing or altering the electoral or voting process in favour of a particular party or contestant (Ugoh 2004, p. 164). Electoral violence is executed through, among others, the intimidation of voters and candidates, killings, forceful displacement and unlawful or politically-induced detention.

Perpetrators of such violence, according to Laakso (2007, p. 225) include the ruling regime and its supporters, opposition groups, spontaneous rioters, and extremist organisations that wilfully exclude themselves from formal political activities. Reflecting on the interface between politicking and violence, Anifowoshe (1982, p. 5) suggests that violence is a critical instrument in the hands of both power-seeking and power-holding groups, and is also a strong weapon for groups faced with the prospect of losing power.

There are three main types of electoral violence, namely pre-election, election day, and post-election (Mehler 2007). Of these, Mehler (2007, p. 217) believes that post-election violence, usually caused by flawed or disputed elections, remains the most rampant across sub-Saharan African democracies. Ready instances of this variant include the confrontation that greeted the 1996 municipal elections in Cameroon, the mass protests that followed Kenya's presidential election of 2008, the violent uprising that followed the declaration of General Robert Guei as the winner of the massively-rigged 2000 presidential election in Ivory Coast, and the political and sectarian crisis that erupted in northern Nigeria following the announcement of official results of the 2011 presidential election.

When violence is deployed to influence the electoral process, the aim is to access what Tilly (1999, p. 337) calls 'established places in the structure of power'. When it is used to reject alleged irregularities in the democratic process, the aim is always to forestall being (unjustly) shut out of the structures of power. Prempeh (2008, p. 109) noted that democratic politics in Africa is dominated by 'access' issues, including the right of the opposition to capture power and the desire of the incumbents to retain power at all costs.

As the 2015 elections approached, the spectre of violence was so strong that competing presidential candidates were made to sign a peace agreement tagged 'the Abuja Accord'. The peace pact was facilitated by former United Nations Secretary General, Kofi Anan, and former Commonwealth Secretary General, Sir Emeka Anyaoku. By endorsing the peace document, all the candidates pledged 
to, among others, conduct issue-based campaigns, refrain from inflammatory language and hate speech during campaigns, accept the outcome of the elections in good faith, and refrain from acts of violence or incitement to violence.

However, indications that the Abuja peace pact might be a farcical effort were evident in the outbreak of election-related violence across the country shortly after the peace deal was sealed. President Goodluck Jonathan, for example, was attacked during his campaign visits to Bauchi and Katsina States in the last week of January 2015.

Indeed, the National Human Rights Commission (NHRC), in its pre-election report on the 2015 general elections, found that 58 people were killed in more than 60 reported incidents of election-related violence between December 2014 and February 2015. In its pre-election report, the $\operatorname{NHRC}(2015$, p. 9) warned that if the trend continued, electoral violence 'could pose a clear and present danger to the stability of the country and its neighbours'.

The urgency of the issue was further underlined by a statement issued on 16 March 2015 by the International Criminal Court (ICC) prosecutor, Fatou Bensouda, indicating the readiness of the global human rights oversight institution to 'prosecute individuals responsible for the commission of ICC crimes whenever necessary'.

This unfortunate turn of events compelled another peace initiative. The two major presidential contenders, President Jonathan and General Buhari, signed a fresh peace accord on 26 March 2015 in Abuja. The new peace accord (which was a follow-up to the 14 January 2015 agreement) was initiated by the National Peace Committee on 2015 Elections, headed by General Abdulsalami Abubakar, Nigeria's former military ruler. The committee was convened by Bishop Matthew Hassan Kukah, founder of the Kukah Centre for Faith and Leadership Research and the Catholic Bishop of Sokoto Diocese.

Members of the committee were General Abubakar; Alhaji Aliko Dangote; Commodore Ebitu Ukiwe (retired); Catholic Bishop of Abuja Diocese, John Cardinal Onaiyekan; Sultan of Sokoto, His Eminence Sa'ad Abubakar; Alhaji Muhammad Musdafa; Primate of Anglican Church, Most Reverend Nicholas Okoh; President of the Christian Association of Nigeria, Pasto Ayo Oritsejafor; Professor Ibrahim Gambari; Justice Rose Ukeje; Professor Bolaji Akinyemi; Professor Ameze Goubadia; Professor Zainab Alkali; Mr Sam Pemu-Amuka; Dame Priscilla Kuye; and Bishop Kukah. The committee was essentially formed to ensure full compliance with the Abuja Peace Accord that had been signed in January 2015.

The intervention of the committee, however, and the earlier efforts of other peace builders, could not prevent pockets of violence that marred the presidential election in some states of the Federation. For example, on 17 February 2015, 
gunshots and explosions boomed at the APC governorship rally held at Okrika National Secondary School, Okrika Rivers State. The incident resulted in the death of one policeman, with several other people being wounded.

On 1 March 2015, two members of the Accord Party (AP), Kehinde Bello and Sarafa Adedeji, were shot dead, while 15 other people sustained varying degrees of injury in Odinjo area of Ibadan, capital city of South Western State of Oyo. On 14 March 2015, unknown assailants killed two chieftains of PDP in Abomena town, Akuku-Toru Local Government Area of Rivers State. Two days later, on 16 March 2015, the convoy of Mrs Aishat Buhari, wife of the presidential candidate of APC, was attacked in Ilorin, Kwara State.

On 18 March, Mr Okon Uwah, a House of Assembly APC candidate seeking to represent the Ukanafun Local Government Area of Akwa Ibom State, was killed by unknown assailants. Two people were killed in Oyo town on 23 March 2015 during the campaign rally of the Social Democratic Party (SDP), organised to drum up support for its gubernatorial candidate, Seyi Makinde.

There were also media reports that the Governor of Rivers State, Chibuike Amaechi, was attacked by unidentified people during a door-to-door campaign in Rumuolumeni, Obio / Akpor local government area of Rivers State on 26 March 2015. Two people were killed by gunmen on the polling day of presidential elections in Nafada Local Government Area of Gombe State, and another two people were killed in Ife and Ikirun areas of Osun State on the same day. Twin explosions also rocked Enugu on the day of the presidential election.

It should be stressed that though these unfortunate incidents happened despite the peace efforts, the relative post-election peace in the country can be largely attributed to those peace initiatives.

\section{THE VOTE AND THE REGIME CHANGE}

On 28 March 2015, Nigerians cast their ballots in the presidential election which had initially been slated for 28 February but had to be shifted by Nigerian authorities (who cited 'security concerns'). Voting took place in 119973 polling units, with 56.4-million registered voters collecting PVCs.

The Independent National Electoral Commission (INEC) accredited 117 local and foreign election monitors to observe at the polls. According to media reports, 300000 police officers, 60000 civil defence personnel, and an unspecified number of sniffer dogs were deployed for the election.

In the official results of the presidential election released by INEC, General Muhammadu Buhari of the APC received a total of 15424921 votes, emerging victorious in the keenly-contested election. Incumbent President Jonathan of PDP received 12853162 votes, clinching second position. 
General Buhari won the election with a 2511759 margin of lead. General Buhari's votes translate to $52.4 \%$ of the total votes cast at the election, which stood at 29432 083, whereas Jonathan's votes translate to $43.7 \%$ of the national votes.

The election recorded a disappointing voter turnout of $47.1 \%$, lower than the 51.7\% recorded in the 2011 presidential poll. Tables 2 and 3 below present a summary of the detailed results of the election.

Table 2

\section{Summary of official results of 2015 presidential election}

\begin{tabular}{|r|l|l|r|}
\hline S/N & Candidate & Party & Votes Received \\
\hline 1. & BUHARI, Muhammadu & APC & 15424921 \\
\hline 2. & JONATHAN, Goodluck & PDP & 12853162 \\
\hline 3. & AYENI, Musa & APA & 53537 \\
\hline 4. & GALADIMA, Ganiyu & ACPN & 40311 \\
\hline 5. & EKE, Sam & CPP & 36300 \\
\hline 6. & SALAU, Rafiu & AD & 30673 \\
\hline 7. & AHMAD, Mani & ADC & 29666 \\
\hline 8. & CHINEDU, Kelvin & PPN & 24475 \\
\hline 9. & ONOVO, Martin & NCP & 24455 \\
\hline 10. & ANIFOWOSE-KELANI, & AA & 22125 \\
\hline 11. & OKORIE, Chekwas & UPP & 18220 \\
\hline 12. & SONAIYA, Oluremi & KOWA & 13076 \\
\hline 13. & OKOYE, Godson & UDP & 9208 \\
\hline 14. & OWURU, Ambrose & HOPE & 7435 \\
\hline
\end{tabular}

Source: Independent National Electoral Commission, 2015

Table 3

Breakdown of votes cast

\begin{tabular}{|l|r|}
\hline Total Number of Registered Voters & 67422005 \\
\hline Total Number of Accredited Voters & 31746490 \\
\hline Total Number of Valid Votes & 28587564 \\
\hline Total Number of Rejected Votes & 844519 \\
\hline Total Number of Votes Cast & 29432083 \\
\hline
\end{tabular}

Source: Independent National Electoral Commission, 2015 
Of the fourteen candidates who contested the 2015 election, only three, namely President Jonathan, General Buhari and Chief Martin Onovo, had been in the 2011 race. While General Buhari had run on the platform of the CPC (one of the four parties that later merged to form the APC), Onovo had been the standard bearer of the AA in the 2011 presidential vote, which was won by President Jonathan of the PDP.

The 2015 presidential election recorded a total of 844519 rejected or voided votes. This represented $2.87 \%$ of all votes cast. While this figure may seem statistically trivial, it is electorally consequential as it is higher than the total number of votes recorded in about 24 states of the Federation, including the Federal Capital Territory.

Kano State recorded the highest number of votes cast, at 2172 447, while the Federal Capital Territory recorded the lowest number at 316015 votes cast. Lagos State had the highest number of rejected votes at 52 289, representing $3.49 \%$ of the total votes cast for the state. Total votes cast in Lagos State stood at 1495975. Bayelsa State, home state of President Jonathan, had the least number of rejected votes at 4672 , representing $1.26 \%$ of total votes for the oil-rich state. Total votes cast in Bayelsa State stood at 371739.

Gender analysis of the results shows that among the fourteen presidential contestants, only one was a woman: Comfort Oluremi Sonaiya, a professor of French and applied linguistics. She ran on the platform of KOWA Party, and came twelfth in the election with a total of 13076 votes, representing $0.04 \%$ of all votes cast. Mrs Sonaiya's performance paints a grim picture of the prospects of mainstreaming gender in Nigerian politics.

Three main reasons can be advanced for the defeat of President Jonathan and his party at the presidential election. First, and arguably the most important reason, was the apparent declining popularity of the Jonathan presidency. The failure of the administration to decisively tackle bureaucratic corruption or manage the national economy, in a manner that would effectively arrest the worsening economic conditions of the masses, seriously challenged the legitimacy of the regime. In addition, the seeming helplessness of the administration in the face of the growing insurgency in the north-eastern parts of the country was another contributory factor in the defeat of Jonathan. It was widely believed that Boko Haram insurgents had comprehensively overwhelmed government troops and that without external assistance, the extremist group could have seized the entire north-eastern states.

In addition to the regime-specific failures of the Jonathan presidency, the PDP went into the crucial elections as an organisationally-distressed party. The party had been seized by a severe internal crisis shortly after Alhaji Bamanga Tukur assumed national party chairmanship in 2012, and never recovered from this 
crisis - despite the forced resignation of Alhaji Tukur in 2014. The crisis deepened with the adoption of President Jonathan as the sole presidential candidate for the PDP by its National Working Committee (NWC).

Perhaps the most damaging fallout of the crisis was the exit of the former President Olusegun Obasanjo from the party, touted by its members as the largest political party in Africa. After drawn-out speculations about his commitment to the party, the former leader finally dumped the PDP a few weeks prior to the crucial 2015 elections, and he did so in a dramatic manner: he tore up his PDP membership card in public! To keen observers and analysts of the politics of the 2015 elections, Obasanjo's action was both symbolic and ominous, coming on the eve of a crucial election.

The third contributory factor that could explain the defeat of the PDP was the penetrating manner in which the opposition APC carried its message of 'Change' to Nigerians. They depicted the PDP as a corrupt party formulating harsh economic policies that have unleashed untold hardship on most Nigerians. From one campaign rally to another, and through the use of social media, leaders of APC urged voters to support 'Change' to a better Nigeria and to reject a continuity of national woes.

Thus, in a profound way, the performance deficit of the Jonathan administration fed into the deafening shout of 'Change!' across the polity. The consequence was the resounding victory of the APC.

Analyst Lasisi (2015), for example, attributes Buhari's electoral success to his personal qualities of 'integrity and doggedness', which he used as weapons in the electoral battle. These sterling qualities became handy to survive the barrage of hate campaigns mounted by President Jonathan's support groups, including his wife, Patience.

In stark contrast to the pre-election apprehension, the country did not witness any serious breakdown of law and order in the post-election period. President Jonathan, even if reluctantly, conceded defeat and congratulated General Buhari.

Worth mentioning are the efforts of the international community, including the United States of America, the United Kingdom, the Commonwealth, the Economic Community of West African States, the African Union, and the International Criminal Court, aimed at ensuring post-election stability in the country.

\section{THE TRIUMPH, THE EXPECTATIONS AND THE CHALLENGES}

The electoral victory of General Buhari is significant for two main reasons. One, his triumph marks the first time the phenomenon of power alternation took place in the democratic history of Africa's largest democracy. Two, it was also the first time an incumbent president would lose a re-election bid. 
The nationwide jubilation and celebration that accompanied the declaration of General Buhari as the winner of 2015 presidential election points to an important fact: the outcome of the election substantially reflected the pattern of voting during the election. Indeed, the Nigerian voters could be regarded as the most critical faction of the national alliance that ousted the Jonathan presidency from power. Having consciously and strongly used their franchise to effect the regime change they desired, it is legitimate that they expect dividends from that electoral revolution. Having waited a long time for the change, they may have little patience to wait any longer.

Thus, the incoming Buhari presidency needs to be proactive in managing the expectations of the Nigerian people before they degenerate into rising frustrations, which could result in the breakdown of the pre-election alliance. A crisis of expectations, if not creatively managed, could adversely impact on the legitimacy of the new regime. One analyst aptly captured the contradiction, saying:

... given the scale of the rot left by Dr Jonathan and his team, and the drastic remedies the winner will need to administer very deeply and quickly, the infatuation between the voters and the APC could very well quickly turn into frustration, or worse, repudiation.

(Akinlotan, 2015)

It is gratifying that the enormity of the issue at hand was not lost on the person who symbolises democratic revolution in Nigeria. General Buhari, in his postelection acceptance speech, said:

I realise that the expectation of our people today is as high as their commitment to change has been strong, and their belief in us, unshaken. While we pledge to begin doing our best without delay, we would like to appeal to them to appreciate the gravity of our situation, so that we become more realistic in our expectation.

Among their other expectations, Nigerians expect the new regime to design policies aimed at improving their material conditions, having been impoverished by the economic agenda of the Jonathan administration. They also expect the new government to embark on institutional renewal, wage a strong war against corruption, initiate the reform of the justice sector, work for increased constitutionalism and more responsible governance, and encourage greater government-citizen engagement.

Improving the material conditions of the citizenry requires repositioning of the national economy. Rated as Africa's biggest economy, Nigeria paradoxically 
remains one of the poorest countries in the world. Growing poverty in the country challenges official claims of impressive economic growth. It will also require fixing the power sector and ensuring adequate protection of lives and property.

Institutional rebirth is imperative against the backdrop of institutional decay that has been witnessed in the country over the years. The zero-sum character of Nigerian politics, the 'do or die' approach of the Nigerian politicians, and the desperate bid to retain power demonstrated by the Jonathan presidency have greatly compromised many public institutions, particularly the military and public media. Corruption, as a national challenge, has not only diverted public resources that could have been deployed into infrastructural and other pro-poor projects into private pockets, but has also rendered ineffective, or comatose, other critical sectors of the economy.

For instance, in spite of the billions of naira invested to improve the power sector by successive administrations, rather than this huge investment translating into light, darkness has been unleashed on hapless Nigerians. In a probe instituted by the lower chamber of the Federal Legislature on the power sector in 2009, the House Committee on Power found that many of the Independent Power Projects (IPP) never took off, despite huge contract sums paid by the government (Animashaun 2010, p. 44).

Crackdowns on independent media, disregard of court orders, and misuse of state instruments for coercion were among the assaults on constitutionalism that were perpetrated by the Jonathan administration. Such occurrences almost put the nation on the road to fascism. It is interesting to note that the new VicePresident, Yemi Oshinbajo, is a professor and teacher of law. He will be expected to bring his deep knowledge and practise of the law to bear in the conduct of government business. Indeed, he will be expected to moderate the dictatorial instincts of the president as a retired army general.

It would be naïve to assume that the efforts of the Buhari presidency at national rebirth would not be marked by challenges. Paths to governance renewal in all climes are beset by challenges. The parlous state of the Nigerian economy will be a potent challenge to the aspirations of the new government. The regime inherited a sick economy that was troubled by dwindling national revenue, occasioned by low oil prices. This scenario is further aggravated by a drop in the external savings of the country. Nigeria's external reserve was placed at $\$ 29.79$-billion in March 2015, down from \$31.35-billion (4.9\%) in February of the same year.

The second challenge is how President Buhari will assemble a team comprising nationalistic, altruistic, patriotic and committed individuals imbued with a deep sense of public service. This unusual time demands an unusual team, populated by people of proven integrity and tested competence, who will approach the national rebuilding project with an uncommon passion. 
The new men and women of power would have to redefine the essence of state power and shift away from the entrenched perception of state power as an instrument of primitive accumulation. If the new government is able to overcome these challenges, the country may well be on the path of economic and political renaissance.

\section{LESSONS LEARNT}

The most important lesson to be drawn from the 2015 presidential vote in Nigeria is that when a people resolutely decides to effect revolutionary change, no amount of effort by the reactionary forces can abort such a determined move. The outcome of the 2015 presidential election profoundly demonstrates the strength of the collective will of the Nigerian people to put a stop to the old order. They did so emphatically and successfully in spite of the overwhelming odds.

Another major lesson from the presidential and parliamentary elections is that having access to considerable funds does not always win elections. Despite the massive material resources at the disposal of President Jonathan, including the electoral advantage offered by the power of incumbency, he lost his bid for re-election. The same fate befell some sitting governors who contested but lost parliamentary elections in their respective states. These governors included those of Bauchi, Benue and Niger States. What these electoral upsets suggest is that financial muscle alone does not win elections (Ojo 2015).

Furthermore, the success recorded in the management of the 2015 Nigeria elections has shown that with sufficient resources and the requisite institutional autonomy, INEC could deliver credible elections whose outcomes reflect the voting preferences of the people. The series of reforms undertaken by the election oversight body, including the use of PVC and SCR, and the transparent manner in which the elections were managed, not only ensured that the votes were properly counted but also enhanced the integrity of the elections. This was confirmed by the reports of both local and foreign election observers who monitored the polls.

For instance, in its First Preliminary Statement on the 2015 Nigeria Elections issued on 30 March 2015, the European Union Election Observation Mission (EU-EOM) reported that, while the elections tested the Nigerian electoral arrangements, INEC made commendable efforts at strengthening the electoral arrangements and there was 'no evidence of systematic manipulations'.

In the same vein, in its preliminary statement released on 30 March 2015, the National Democratic Institute (NDI) noted that voting and counting of ballots showed remarkable improvements in efficiency and adherence to procedures that enhanced the transparency and integrity of the exercise.

Punch, in its editorial titled 'Buhari, Dawn of a New Era', described the 
2015 general elections as 'a marked improvement on past elections where logistical, ethical and administrative issues dented the integrity of polling and made Nigeria a laughing stock around the world...' (Punch, 1 April 2015). The institutional efficiency exhibited by INEC in respect of the 2015 elections, if sustained, would serve as an asset for the election management body in its management of future elections.

\section{CONCLUDING REMARKS}

Two issues should bother the scholarly community as the euphoria of the success of the 2015 elections winds down. First, the disappointing voter turnout at the election should be a subject of intellectual scrutiny. There is a tendency to explain away the poor voter turnout that marked the presidential and parliamentary polls by reference to the apprehension that preceded the first round of the 2015 elections. However, given the relative peace and low incidence of violence during the national elections, 'voter disappearance' - which characterised the second leg of the elections (state elections) - suggests that little importance should be attached to a single factor, such as violence, in explaining voter apathy.

The challenge to political scientists is to understand the overarching explanatory variables that influence political participation, specifically that of voting during elections. Thus, empirical investigations need to be undertaken in order to offer scientifically valid explanations for the voter apathy in such historic elections. The central objective of the empirical study should not only be to explain decreasing voter turnout, but to establish why voter turnout was so low in the first instance. Fewer than $50 \%$ of accredited voters supplied General Buhari's mandate.

Admittedly, global democracy is facing a crisis of participation, deriving largely from voter disillusionment with party democracy. The consequence of this, as observed by Newton and Norris (2000, p. 71) is the disengagement of citizens from the political process, and a decline in levels of citizen confidence in political leadership and democratic institutions. However, in respect of the 2015 Nigeria elections, the disappointingly low voter turnout is worrisome especially because the presidential election was the most closely and keenly contested since the re-inauguration of constitutional rule in 1999.

In addition, voter apathy occurred despite the commendable mobilisation and voter education efforts of the INEC, National Orientation Agency (NOA), political parties and civil society organisations.

The second issue that requires scholarly analysis is violence during the elections. Although the incidence of violence was low, government must take appropriate punitive actions against all those who were implicated in the pockets 
of violence recorded during the elections. While violence did not occur on the large scale that was feared before the elections, those who were involved in the few incidents should be brought to justice. This would help to deter future merchants of violence. It would also help to restore citizens' confidence in the state's capacity to enforce its own laws. Available evidence suggests that the culture of impunity is an entrenched feature of electoral competition in Nigeria.

The Bolarinwa Babalakin Judicial Commission of Inquiry into the activities of the former Federal Electoral Commission (FEDECO) in 1986, for example, lamented that 'the abuse of the nolle prosequi and pardons' by the government encouraged lawlessness during the 1979 and 1983 election periods (FGN 1986, p.10). Similarly, the Sheikh Lemu panel instituted by the Federal Government to investigate the post-election violence that erupted in Nigeria after the 2011 presidential election, documents that

[T] here was not a single arrest of any person in connection with those killings in Kaduna State South Senatorial District. This raised very great concerns on why or how this happened or what guarantees there are to prevent such terrible killings in the future.

(FGN 2012, p. 217)

The importance of these examples is that the lack of a strong will on the part of the state to directly confront the conundrum of political violence is a major explanation for the continuation of violence in the political and social life of the country. Among other instruments, Nigeria is not lacking in elaborate laws designed to check political and electoral violence, as evidenced by several provisions in the 1999 Constitution, as amended. These include the 2010 Electoral Act, as amended, and the Code of Conduct for political parties. What has been tragically absent is the strict enforcement of these provisions with a view to sanctioning perpetrators of violence for their dastardly acts (Ojo 2015). This enforcement deficit represents a huge challenge to the new administration in Nigeria.

\section{REFERENCES}

Adekanye, JA1989, 'Nigerian armed forces to take over conduct of future elections', The Quarterly Journal of Administration. vol. 23, no 1 \& no 2, October 1988January 1989.

Agomor, K \& Adams, S 2014, 'Determinants of voting behaviour in Ghana', paper presented at the $23^{\text {rd }}$ annual conference of Global Awareness Society International, May 2014, Montego Bay, Jamaica. 
Aina, AD 2004, 'Party and electoral politics', in A Agbaje, L Diamond and E Onwudiwe (eds), Nigeria's struggle for democracy and good governance, Ibadan University Press, Ibadan.

Akinlotan, I 2015, The nation on Sunday, 'Buhari's Delicate Victory', 5 April.

Albert, IO 2007, 'Reconceptualizing electoral violence in Nigeria', in I Albert, D Marco \& V Ochoche (eds), Africa Peace Review, vol. 1, no 1, pp. 38-52.

Anifowoshe, R 1982, Violence and politics in Nigeria: the Tiv and Yoruba experience, Nok Publishers, New York.

Animashaun, MA 2010, 'The legislature and fiscal oversight in Nigeria: 1999-2010', UNIOSUN Journal of Politics and Society, vol. 1, no 1, p. 44.

Animashaun, MA 2014, '2010 Electoral Act, party funding and prospects of alternation of power in Nigeria', African Journal of Peace and Security, vol. 3, no 1, pp. 18-32.

Azzez, A 2004, 'Political violence in Nigeria: current trends and manifestations', Political Science Review, vol. 3, no 1 \& no 2, March, pp. 160-169.

Bakare, AR 2014, 'Unsafe at any margin: interpreting the SWOT analysis of President Jonathan's political future in Nigeria', Political Science Review, vol. 6, no 1, pp. 248-260.

Bekoe, D 2011, Nigeria's 2011 elections: best run but most violent, United States Institute of Peace, Washington DC.

Eckstein, H \& Gurr, T 1975, Patterns of authority: a structural basis for political inquiry, Wiley, New York.

Elaigwu, J 2003, 'Causes, manifestation and consequences of electoral violence in Nigeria', paper presented at the National Conference on Strategies for Curbing Election-Related Violence in Nigeria, organised by Mambiyya House, Bayero University, Kano, July 25-27.

Erdman, G 2007, 'Ethnicity, voter alignment and political party affiliation in an African case: Zambia', GIGA Working Paper 45, German Institute of Global and Area Studies, Hamburg.

Eulau, H 1960, book review of 'The American Voter', American Political Science Review (54), pp. 993-94.

Fayemi, K 2015, 'Re: Buhari versus Jonathan: beyond the election', Vanguard Newspaper, 27 January.

Fayemi, JK 2003, 'Entrenched military interests and the future of democracy in Nigeria', in AT Gana \& SG Egwu (eds), Federalism in Africa: the imperative of democratic development, vol. 2, Africa World Press Inc, Trenton.

FGN: Federal Government of Nigeria 1986, Report of the Judicial Commission of Inquiry into the affairs of the Federal Electoral Commission (FEDECO) 1979-1983, main report, Federal Government Printer, Lagos. 
FGN: Federal Government of Nigeria 2012, Main report of the Federal Government investigative panel on 2011 election violence and civil disturbances, vol. 1, Federal Government Printer, Abuja.

HRW: Human Rights Watch 2011, 'Nigeria's post election violence killed 800', HRW, Washington DC, available at http:/ / www.hrw.org/news/2011/05/16/ nigeria-post-election-violence-killed-800 retrieved 23 November 2014.

Ibeanu, O 2012, 'Foreword', in N Orji \& N Uzodi (eds), The 2011 post-election violence in Nigeria, Policy and Legal Advocacy Centre (PLAC), Abuja.

IEP: Institute for Economics and Peace 2014, Global peace index 2014: measuring peace and assessing country risk, IEP Report 28, IEP, Sydney and New York.

ICG: International Crisis Group 2014, Nigeria's dangerous 2015 elections: limiting the violence. Africa Report No 220, ICG, Brussels.

Joseph, RA 1991, Democracy and prebendal politics in Nigeria: the rise and fall of the second Republic, Spectrum Books, Ibadan.

Kurfi, A2003, Improving management of Nigeria's electoral process: problems and prospects, International Human Rights Law Group, Abuja.

Laakso, L 2007, 'Insights into electoral violence in Africa', in M Basedau, G Erdmann \& A Mehler (eds), Votes, money and violence: political parties and elections in subSaharan Africa, The Nordic Africa Institute and University of KwaZulu-Natal, Uppsala and Scottsville.

Lasisi, A 2015, Punch Newspaper, 'Dawn of a new General', 1 April.

Lazarfeld, PF, Berelson, B, \& Gaudet, H 1948, The people's choice: how the voter makes up his mind in a presidential campaign ( $2^{\text {nd }}$ ed), Columbia University Press, New York.

Lindberg, S \& Morrison, M 2008, 'Are African voters really ethnic or clientelistic? Survey evidence from Ghana', Political Science Quarterly, 123 (1), pp. 95-122.

Mehler, A2007, 'Political parties and violence in Africa: systematic reflections against empirical background', in M Basedau, G Erdmann \& A Mehler (eds), Votes, money and violence: political parties and elections in sub-Saharan Africa, The Nordic Africa Institute and University of KwaZulu-Natal, Uppsala and Scottsville. NHRC: National Human Rights Commission 2015, A pre-election report and advisory on violence in Nigeria's 2015 general elections, NHRC, Abuja, 13 February.

NAPEN: National Association of Peaceful Elections in Nigeria 2011, Nigeria's Electoral Violence Report (NEVR), Project Final Report, NAPEN, Abuja.

Newton, K \& Norris, P 2000, 'Confidence in public institutions: faith, culture and performance', in S Pharr \& R Putnam (eds), Disaffected democracies, Princeton University Press, Princeton.

Nwolise, OBC 2007, 'Electoral violence and Nigeria's 2007 elections', Journal of African Elections special issue: Nigeria's 2007 general elections, vol. 6, no 2, October. 
Ochoche, S 1997, 'Electoral violence and national security in Nigeria', Africa Peace Review, vol. 1, no 1, April, pp. 13-25.

Ojo, J 2015, Punch Newspaper, 'The good, the bad and the ugly sides of 2015 elections', 1 April.

Omitola, BO 2011, 'Political parties' competition, electoral violence and democratic consolidation in Nigeria's Fourth Republic: 1999-2007', in I Ogundiya (ed). Political parties and democratic consolidation in Nigeria, Codat Publications, Ibadan.

Prempeh, HK 2008, 'Presidents Untamed', Journal of Democracy, vol. 19, no 2, April, pp. 109-123.

Quantin, P 1998, 'Pour une analyse comparative des elections Africaines', Politique Africaine 69, pp. 13-26.

Reychler, L 1999, Democratic peace-building and conflict prevention: the devil is in the transition, Leuven University Press, Leuven.

Tilly, C 1999, 'Power - top down and bottom up', Journal of Political Philosophy, vol. 7, pp. 330-352.

Vanguard Newspaper, Soludo, C 2015, 'Buhari versus Jonathan: Beyond the Election', 27 January.

Ugoh, C 2004, 'Electoral malpractices and violence in the 2003 general elections in Nigeria', Unilag Journal of Politics, vol. 1, no 1, December, pp. 164-186.

Yaqub, NO 2003, 'Inter and intra party conflicts and the future of democracy in Nigeria', in BA Olasupo (ed), Electoral violence in Nigeria: issues and perspectives, Friedrick Ebert Stiffung, Lagos, pp. 97-114. 